\title{
Analisis Korelasi Sikap Siswa dan Disiplin Siswa terhadap IPA pada Siswa SMP di Propinsi Jambi
}

\author{
${ }^{1}$ Dwi Agus Kurniawan, ${ }^{1}$ A Astalini, ${ }^{1}$ Nugroho Kurniawan, ${ }^{1}$ Haerul Pathoni \\ 1 Prodi Pendidikan Fisika, Universitas Jambi, Jambi Luar Kota 36361, Indonesia \\ e-mail: dwiagus.k@unja.ac.id; astalinizakir@unja.ac.id; kurniawan.nk97@gmail.com; \\ haerul.pathoni@gmail.com
}

\begin{abstract}
Abstrak
IImu Sains dan karakter dalam pendidikan menjadi fokus penting dalam efektivitas dan keberhasilan pembelajaran. Penelitian ini bertujuan untuk melihat sikap siswa terhadap sains dan melihat disiplin siswa terhadap sains, kemudian menganalisis korelasi antara dua variabel (sikap dan disiplin) tentang sains. Penelitian ini menggunakan penelitian survei. Instrumen Penelitian: sikap siswa dan disiplin siswa terhadap sains, yang terdiri dari 25 pernyataan untuk setiap variabel. Penlitian ini dilaksanakan kepada 864 siswa/i SMP di Provinsi Jambi. Hasil penelitian menunjukkan bahwa: (1) indikator sikap siswa terhadap sains menunjukkan sikap positif (kategori baik), (2) indikator disiplin siswa terhadap sains menunjukkan hasil positif, (3) statistik korelasi antara sikap siswa dan disiplin menunjukkan korelasi positif, dengan perincian; Kelas 7 memiliki korelasi yang sangat kuat $(0,696)$, kelas 8 memiliki korelasi yang sangat kuat $(0,828)$, dan kelas 9 memiliki korelasi yang kuat $(0,696)$. Kesimpulannya: variabel sikap siswa dan disiplin siswa menunjukkan hasil positif dan setiap kelas memiliki korelasi positif dan mayoritas tingkat kelas memiliki kategori korelasi yang sangat kuat. Artinya penguatan karakter sikap dalam sains akan diikuti dengan penguatan karakter disiplin dalam sains.
\end{abstract}

Kata Kunci: pendidikan sains; pendidikan karakter; sikap siswa; disiplin siswa

\section{Correlation Analysis of Student Attitudes and Student Discipline on Science in Junior High School Students in Jambi Province}

\begin{abstract}
Science and character in education become an important focus in the effectiveness and success of learning. This study aims to look students' attitudes towards science and look students' disciplines towards science, then analyze the correlation between two variables (attitudes and disciplines) regarding science. This study uses survey research. Research Instruments: student attitudes and student discipline towards science, which consists of 25 statements for each variable. This research was conducted on 864 Junior High School in jambi Province. The results showed that: (1) the indicators of student attitudes towards science showed a positive attitude (good category), (2) the indicators of student disciplines towards science showed positive results, (3) statistics of correlations between student attitudes and disciplines showed positive correlation, with details; 7th grade has a very strong correlation $(0.696), 8$ th grade has a very strong correlation $(0.828)$, and 9th grade has a strong correlation (0.696). In conclusion: the variable student attitudes and student discipline showed positive results and each class had a positive correlation and the majority of level grade have a very strong correlation category. it means that the strengthening of the attitude character in science will be followed by strengthening the character of discipline in science.
\end{abstract}

Keywords: science education, character education, students' attitudes, students' disciplines, Jambi Province

How to Cite: Kurniawan, D., Astalini, A., Kurniawan, N., \& Pathoni, H. (2019). Analisis korelasi sikap siswa dan disiplin siswa terhadap IPA pada Siswa SMP Provinsi Jambi. Jurnal Pendidikan Fisika dan Keilmuan (JPFK), 5(2), 59-71. doi:http://dx.doi.org/10.25273/jpfk.v5i2.5014 


\section{PENDAHULUAN}

Pendidikan merupakan kegiatan yang sangat penting bagi semua individu, karena pendidikan mampu merubah tingkah laku dan pengetahuan individu menjadi lebih baik. Pendidikan memiliki peran sangat penting pada suatu bangsa untuk berkembang maju dan sejahtera (Aithal \& Aithal, 2015). Puspita (2019) menyatakan "Peningkatan mutu sumber daya manusia ditentukan oleh kualitas pendidikan yang semakin baik". Sehingga pendidikan merupakan salah satu kebutuhan pokok bagi setiap individu karena berkaitan dengan kehidupan suatu bangsa. Manan (2015) tanpa pendidikan, maka kesulitan untuk individu turut aktif berpartisipasi di era globalisasi dan sulit memperoleh kesempatan. Pendidikan bergerak setiap tahun dari satu tahap ke tahap pengembangan berikutnya yang memiliki karakteristik dan tantangan pendidikan yang berbeda (Acosta, 2016). Ciri khas dan tantangan pendidikan tersebut yang membuat setiap negara memiliki pandangan berbeda, misalnya masalah pendidikan, kurikulum, tujuan pendidikan, proses pembelajaran.

Keberhasilan terhadap proses pembelajaran dapat ditunjukkan pada tercapainya kompetensi belajar (Febriana dkk., 2018). Pengembangan pembelajaran pada setiap siswa tingkat menengah perlu memperhatikan strategi pembelajaran yang tepat. Strategi pembelajaran ini yang mempengaruhi tingkat efektifitas dan keberhasilan dalam belajar. Ulstad dkk. (2016) strategi pembelajaran tidak hanya membantu siswa mendapatkan nilai yang lebih baik, tetapi juga membantu mereka mencapai tujuan utama yang disajikan kurikulum. Sehingga kurikulum berkaitan langsung dengan kurikulum. Kurikulum layaknya seperti kompas yang memandu kapal, sehingga kurikulum berperan penting dalam mengatur, mengarahkan, dan membimbing kegiatan pembelajaran (Rumahlatu dkk., 2016). Kurikulum pendidikan umumnya berisi tentang panduan dalam pembelajaran. Maka kurikulum dan pendidikan seharusnya menjadi perhatian khusus.

Desain dan evaluasi kurikulum memberikan standar berdasarkan tujuan untuk upaya merespon keterampilan dan pembelajaran berbasis konten (Sparapani \& Perez, 2015). Perhatian terhadap pengetahuan dalam pendidikan tidak hanya terfokus pada indikator keberhasilan pendidikan, melainkan juga memiliki perhatian pada dimensi dan aspek nilai, sikap, perilaku, dan karakter siswa (Abdullah, 2016). Sehingga kurikulum pendidikan juga memastikan pengembangan karakter dalam keberhasilan pendidikan. Kurikulum pendidikan 2013 di Indonesia berfungsi juga untuk menjawab tantangan dunia dalam bidang pendidikan. Kurikulum 2013 di Indonesia dalam aspek luas materi pelajarannya bukan hanya dalam ruang lingkup nasional, tetatpi juga memenuhi tantangan pendidikan dunia (Prihantoro, 2015). Kurikulum 2013 membawa pendekatan ilmiah pada proses (Kusumaningsih, 2013). Curriculum 2013 brings the scientific approach in the learning process (Kusumaningsih, 2013). Kurikulum 2013 menggunakan pendekatan saintifik yang bertujuan untuk menuntut siswa aktif dalam belajar. Diberlakukannya kurikulum 2013 proses pembelajaran menekankan fokus pada keaktifan siswa, tujuannya agar siswa mampu mengembangkan sikap-spiritual, sosial, pengetahuan dan keterampilan, selain itu diharapkan siswa mampu menerapkan materi dan dapat berpikir kritis.

Salah satu pembelajaran yang diajarkan dalam suatu kurikulum pendidikan adalah pembelajaran sains. Pengetahuan Sains merupakan ilmu yang mempelajari terkait hal bersifat empiris dan eksakta, umumnya konsep kajian sains adalah berkaitan fenomena alam, makhluk hidup, dan kajian alamiah. Konteks sains 
memiliki tiga domain nilai dalam masyarakat: nilai-nilai pendidikan, nilai-nilai sains alamiah., dan nilai-nilai pendidikan sains (Chowdhury, 2018). Science is composed by explaining Natural and social phenomenon of students as asking for scientific and organizing and creating thoughts and ideas (Kang \& Noh, 2017). Era perkembangan sains dan teknologi menjadikan IPA/Sains sangat penting bagi setiap individu (Nursa'adah, 2015). Maka, sains akan efektif untuk dipelajari jika setiap siswa memiliki perilaku dan karakter yang baik

Selain untuk menguatkan dan mengembangkan pelajaran, maka kurikulum juga menguatkan pendidikan karakter pada siswa. Karakter adalah karakteristik istimewa yang melekat pada diri seseorang, umumnya karakter terbentuk secara konsisten dan dapat diprediksi melalui kencederungan perilaku (Fahmy dkk., 2015). Karakter adalah objektivitas baik yang menunjukkan kualitas manusia (individu) (Lickona, 2004). Maka, setiap siswa seyogyanya menerapkan karakter dalam proses pendidikannya. Menjalankan pendidikan dengan mengabaikan nilainilai dan pendidikan karakter akan membawa masalah baru, yaitu penurunan nilai moralitas atau karakter (Warsito \& Asrowi, 2017). Pendidikan karakter dalam pembelajaran seyogyanya adalah kewajiban untuk diimplementasikan dalam berbagai bidang mata pelajaran (Widodo \& Pranata, 2018). Karkakter yang baik pada siswa akan menunjukkan hasil yang positif pada pembelajaran sains.

Sikap adalah penilaian setiap individu terhadap suatu objek. Objek pada sikap bisa konkret atau abstrak, dan menyimpulkan kebribadian seseorang. Sikap umumnya berhubungan dengan kepercayaan/perasaan setiap individu yang bersifat stabil dan sulit diubah. Menurut Bennett (2003) "There is a considerableconsensus of opinion that the promotion of favorable attitude is an important aim of science education". Sehingga sikap terhadap sains sangat penting bagi siswa, hal ini menunjukkan bagaimana siswa berpendapat dan mengungkapkan ekspresi tentang sains.

Disiplin merupakan perilaku yang melekat pada setiap orang, dan krusial karena berkaitan dengan perilaku/karakter setiap orang. Setiap individu membutuhkan sikap disiplin, karena dengan disiplin kehidupan individu menjadi teratur (Trisnawati, 2013). Damrongpanit (2019) disiplin diri adalah salah satu kualifikasi untuk semua masyarakat dan orang yang dibutuhkan. Disiplin terhadap siswa erat kaitanya dengan permasalahan dari siswa dan sekolah. Pendekatan disiplin sekolah saat ini, terutama digunakan untuk masalah siswa dan komunitas sekolah (Winkler dkk., 2017). Disiplin merupakan komponen karakter yang tidak boleh dipisahkan oleh setiap siswa. Konsekwensinya, disiplin biasanya merefleksikan nilai dan norma pada individu atau kelompok. Disiplin mempunyai efek positif dalam pembelajaran di sekolah.disiplin di kelas di anngao sebagai salah satu kunic pembelajaran yang efektif (Ugurlu dkk., 2015). Sedangkan disiplin siswa terhadap sains merupakan perilaku kebiasaan yang dilakukan secara konsisten terhadap sains(IPA).

\section{METODE PENELITIAN}

Penelitian ini menggunakan penelitian survey. Creswell (2002) desain penelitian survei adalah prosedur dalam penelitian kuantitatif dimana penelitian mengelola survei dari sampel atau populasi untuk tujuan mendeskripsikan sikap, pendapat, perilaku, atau karakteristik dari responden. Responden penelitian ini merupakan siswa SMP di Provinsi Jambi, Indonesia. Sampel penelitian menganalisis 864 responden siswa SMP. Sampel terdiri dari 287 siswa kelas 7, 283 siswa kelas 8, dan 294 siswa kelas 9 yang menggunakan teknik purposive 
sampling. Purposive sampling merupakan teknik pengambilan sampel berdasarkan kriteria yang ditetapkan oleh peneliti (Creswell, 2002). Pengumpulan data penelitian berasal dari intsrumen penelitian yang berasal dari angket. (Cohen dkk., 2013) "The researcher will have to judge the appropriateness of using a questionnaire for data collection, and, if so, what kind of questionnaire it will be". Instrumen penelitian terdiri dari angket sikap terhadap sains dan angket disiplin siswa terhadap sains. Kedua angket ini menggunakanan skala likert. Joshi dkk. (2015) kala likert diterapkan sebagai salah satu alat psikometrik dalam penelitian ilmiah. Pengumpulan data dilakukan dengan memberikan kedua angket kepada siswa sebagai sampel/responden. Berikut adalah tabel indikator sikap siswa terhadap sains dan disiplin siswa terhadap sains.

Tabel 1. Indikator sikap siswa terhadap IPA (Sains)

\begin{tabular}{llc}
\hline No & Indikator & Pernyataan \\
\hline 1 & Adopsi sikap ilmiah & 6 \\
2 & Kesenangan belajar pada Sains & 6 \\
3 & Ketertarikan meluangkan waktu pada sains & 7 \\
4 & Minat berkarir pada bidang Sains & 6 \\
\hline & Total Pernyataan & 25 \\
\hline
\end{tabular}

Tabel 2. Indikator Disiplin Siswa terhadap Sains

\begin{tabular}{llc}
\hline No & Indikator & Pernyataan \\
\hline 1 & Disiplin mengikuti pelajaran IPA di sekolah & 4 \\
2 & Disiplin dalam mengerjakan tugas sains/IPA & 7 \\
3 & Disiplin belajar IPA di rumah & 6 \\
4 & Disiplin mentaati tata tertib sekolah & 8 \\
\hline & Total Pernyataan & 25 \\
\hline
\end{tabular}

Teknik analisis data penelitian menggunakan 2 statistik, yaitu; analisis statistik deskriptif dan statistik inferensial. Pengolahan analisis data angket menggunakan software olah data IBM Statistics SPSS yang digunakan untuk mendapatkan hasil dari deskriptif dan inferensial dalam penelitian ini. Selain menggunakan angket, peneliti juga melakukan wawancara yang bertujuan untuk memperkuat data kuantiatif yang telah didapatkan.

\section{HASIL DAN PEMBAHASAN}

\section{Sikap Terhadap Sains}

a. Adopsi Sikap IImiah

Sikap ilmiah adalah salah satu indikator dari sikap positif siswa terhadap sains (Astalini dkk., 2019). Sehingga terdapat korelasi positif antara sikap siswa dengan pengetahuan ilmiah. Adopsi sikap ilmiah menjadi penting karena mendorong siswa dapat lebih sensitif terhadap sains dengan cara bersikap secara ilmiah. Sikap ilmiah juga membantu dalam pembelajaran sains mereka. Salah satu fokus pada sains adalah mampu menemukan strategi dan metode pengajaran yang bertujuan untuk meningkatkan pembelajaran dan pengalaman siswa pada sains (IPA) (Abed, 2016). Selanjutnya pada Tabel 3 menunjukkan bahwa kategori bauk menunjukkan hasil dominan dengan 51,7\% atau 447 dari 864 siswa. sedangkan kategori sangat baik ialah $7,1 \%$ atau 61 siswa. 
Tabel 3. Adopsi Sikap IImiah

\begin{tabular}{|c|c|c|c|c|c|c|c|}
\hline \multicolumn{3}{|c|}{ Klasifikasi } & \multirow{2}{*}{$\%$} & \multirow{2}{*}{$\begin{array}{l}\text { Standar } \\
\text { Deviasi }\end{array}$} & \multirow{2}{*}{ Mean } & \multirow{2}{*}{ Modus } & \multirow{2}{*}{ Median } \\
\hline Rentang & Sikap & Jumlah & & & & & \\
\hline $6.0-10.8$ & Sangat Tidak Baik & 1 & 0.1 & & & & \\
\hline $\begin{array}{l}10.9-15.6 \\
15.7-20.4 \\
20.5-25.2\end{array}$ & $\begin{array}{l}\text { Tidak Baik } \\
\text { Cukup } \\
\text { Baik }\end{array}$ & $\begin{array}{l}34 \\
321 \\
447\end{array}$ & $\begin{array}{l}3.9 \\
37.2 \\
51.7\end{array}$ & 0.68 & 3.62 & 4.0 & 4.0 \\
\hline \multirow[t]{2}{*}{$25.3-30.0$} & Sangat Baik & 61 & 7.1 & & & & \\
\hline & Total & 864 & 100 & & & & \\
\hline
\end{tabular}

Hasil wawancara sikap siswa menunjukkan hasil baik, artinya siswa mempunyai inisiatif untuk mencari pengalaman belajar sendiri. Sehingga indikator adopsi sikap ilmiah pada penelitian ini menunjukkan sikap siswa lebih dominan dalam kategori baik dan menunjukkan sikap positif siswa terhadap sains berada dalam kategori baik. Kategori sikap baik dari hasil analisis data juga didukung faktor utama, pertama siswa memiliki sikap senang membaca buku pelajaran sains dan memahami aspek-aspek ilmiah. Didukung Sumiati dkk. (2018) sains merupakan hasil produk ilmu ilmiah, maka metode, proses, prinsip, dan hal yang berkaitan sains juga harus ilmiah.

b. Kesenangan dalam Belajar Sains

Kesenangan dianggap sebagai variabel emosional dan konsep penting dalam pembelajaran karena menggambarkan masalah pendidikan kepada siswa (Mohammad-Davoudi \& Parpouchi, 2016). Kesenangan belajar dalam sains menjelaskan tentang tanggapan siswa melalui perasaan senang terhadap pelajaran sains. Dari hasil tabel 4 indikator kesenangan dalam belajar sains secara umum bahwa sikap siswa dominan menuju sikap positif dengan kategori baik.

Tabel 4. Kesenangan belajar IPA/Sains

\begin{tabular}{|c|c|c|c|c|c|c|c|}
\hline \multicolumn{3}{|c|}{ Klasifikasi } & \multirow{2}{*}{$\%$} & \multirow{2}{*}{$\begin{array}{l}\text { Standar } \\
\text { deviasi }\end{array}$} & \multirow{2}{*}{ Mean } & \multirow{2}{*}{ Modus } & \multirow{2}{*}{ Median } \\
\hline Rentang & Sikap & Jumlah & & & & & \\
\hline $6.0-10.8$ & Sangat tidak baik & 2 & 0.1 & & & & \\
\hline $\begin{array}{l}10.9-15.6 \\
15.7-20.4 \\
20.5-25.2\end{array}$ & $\begin{array}{l}\text { Tidak Baik } \\
\text { Cukup } \\
\text { Baik }\end{array}$ & $\begin{array}{c}40 \\
231 \\
411\end{array}$ & $\begin{array}{c}4.6 \\
26.8 \\
47.5\end{array}$ & 0.8 & 3.85 & 4.0 & 4.0 \\
\hline \multirow[t]{2}{*}{$25.3-30.0$} & Sangat Baik & 181 & 21.0 & & & & \\
\hline & Total & 864 & 100 & & & & \\
\hline
\end{tabular}

Hasil wawancara yang dilakukan menunjukkan sikap siswa terhadap matapelajaran sains dalam kategori baik. Artinya, siswa menganggap bahwa sains merupakan salah satu pelajaran yang meyenangkan. Sikap positif tersebut dibuktikan bahwa rata-rata siswa yang setuju bahwa pelajaran sains itu menyenangkan dan juga merupakan salah satu mata pelajaran yang paling menarik. Salah satu contoh kesenangan siswa dalam bidang sains yaitu siswa termotivasi untuk mencari pengetahuan lebih dibidang sains. Kesenangan dianggap mekanisme yang mendorong konsentrasi peserta didik, membantu proses pembelajaran, dan membangun lingkungan belajar (Lucardie, 2014). 
c. Ketertarikan Memperbanyak Waktu Belajar IPA (Sains)

Ketertarikan meluangkan waktu untuk IPA membuar sikap lebih positif terhadap penyelidikan ilmiah dan terhadap ilmuwan untuk siswa (Holstermann dkk., 2010). Ketertarikan pada pelajaran sains memicu \& mempertahankan komponen penting afektif pada sains dan pembelajaran. Penjelasan tersebut menunjukkan bahwa indikator ini berkorelasi dengan sikap siswa pada sains/IPA. Didukung hasil tabel 5 menunjukkan 49.5\% (428 dari 864 siswa) berada pada kategori baik.

Tabel 5. Ketertarikan Memperbanyak Waktu Belajar Sains

\begin{tabular}{|c|c|c|c|c|c|c|c|}
\hline \multicolumn{3}{|c|}{ Klasifikasi } & \multirow{2}{*}{$\%$} & \multirow{2}{*}{$\begin{array}{l}\text { Standar } \\
\text { deviasi }\end{array}$} & \multirow{2}{*}{ Mean } & \multirow{2}{*}{ Modus } & \multirow{2}{*}{ Median } \\
\hline Rentang & Sikap & Jumlah & & & & & \\
\hline $7.0-12.6$ & Sangat tidk baik & 0 & 0.0 & & & & \\
\hline $12.7-18.2$ & Tidak baik & 76 & 8.8 & & & & \\
\hline $18.3-23.8$ & Cukup & 259 & 30.0 & 0.8 & 3.64 & 4.0 & 3.0 \\
\hline $23.9-29.4$ & Baik & 428 & 49.5 & & & & \\
\hline \multirow[t]{2}{*}{$29.5-35.0$} & Sangat baik & 101 & 11.7 & & & & \\
\hline & Total & 864 & 100 & & & & \\
\hline
\end{tabular}

Hasil wawancara tersebut selaras dengan penelitian (Khuzwayo, 2018) belajar sebagai kelompok bermanaat untuk siswa dengan berbagai cara. Sehingga meluangkan/memperbanyak belajar IPA terdapat aspek manfaat untuk siswa. Seyogyanya pembelajaran IPA tujuan utamanya adalah untuk memberikan penguasan konsep-konsep IPA kepada Siswa (Wati dkk., 2018). Kesimpulannya adalah siswa memiliki minat memperbanyak waktu belajar IPA(Sains) berdampak positif pada sikap siswa. Dan dibuktikandari hasil penelitian di atas.

\section{d. Minat Berkarir di Bidang Sains}

Minat dalam belajar sains memicu dan mempertahankan komponen afektif berupa kesenangan yang selaras antara kognitif di kelas, integrasi, dan peningkatkan pengalaman belajar sains. Jadi dapat disimpulkan ketertarikan berkarir dibidang sains mempunyai pengaruh signifikan terhadap pertumbuhan sikap positif. didukung hasil 6 Tabel menunjukkan angka 46,3\% (400 dari 864 siswa) berkategori baik. sikap kategori baik menyimpulkan sikap positif siswa. Didukung juga berdasarkan tabel 6 , siswa sikap yang sangat baik menunjukkan nilai lumayan tinggi, dengan jumlah $11,8 \%$ (102 siswa). Hal ini dikarenakan siswa beranggapan bahwa sains/IPA akan lebih bermanfaat jika siswa mendalami lebih dalam secara konsep dan aplikasi, yang menyebabkan minat mereka yang tinggi untuk berkarir atau melanjutkan studi dibidang sains.

Tabel 6. Minat Berkarir Bidang Sains

\begin{tabular}{|c|c|c|c|c|c|c|c|}
\hline \multicolumn{3}{|c|}{ Klasifikasi } & \multirow{2}{*}{$\%$} & \multirow{2}{*}{$\begin{array}{l}\text { Standar } \\
\text { deviasi }\end{array}$} & \multirow{2}{*}{ Mean } & \multirow{2}{*}{ Modus } & \multirow{2}{*}{ Median } \\
\hline Rentang & Sikap & Jumlah & & & & & \\
\hline $6.0-10.8$ & Sangat Tidak Baik & 4 & 0.5 & & & & \\
\hline $10.9-15.6$ & Tidak Baik & 57 & 6.6 & & & & \\
\hline $15.7-20.4$ & Cukup & 301 & 34.8 & 0.8 & 3.62 & 4.0 & 4.0 \\
\hline $20.5-25.2$ & Baik & 400 & 46.3 & & & & \\
\hline \multirow[t]{2}{*}{$25.3-30.0$} & Sangat Baik & 102 & 11.8 & & & & \\
\hline & Total & 864 & 100 & & & & \\
\hline
\end{tabular}

Dari hasil wawancara dapat disimpulkan siswa sangat tertarik berkarir untuk menjadi ilmuwan sains. Hasil ini dapat disebabkan karena minat siswa pada sains sangat positif. Karena menurut siswa dari wawancara tersebut menyatakan bahwa jika seseorang menjadi ilmuwan sains yang baik, maka akan memberikan dampak positif bagi semua orang pada umumnya. 


\section{Disiplin Siswa Terhadap Sains}

a. Disiplin Mengikuti Pelajaran Sains

Disiplin dalam mengikuti pelajaran di sekolah dapat dimaknai bahawa setiap siswa memiliki kesungguhan dalam belajar disekolah. Sehingga disiplin dalam Mengikuti Pelajaran Sains di sekolah mempunyai pengaruh signifikan terhadap pertumbuhan disiplin yang positif. Tabel 7 menunjukkan $36,6 \%$ (316 dari 864 siswa) berada pada kategori baik dan 28,7\% (248 siswa) pada kategori sangat baik. Hasil menunjukkan tingginya kategori baik menyimpulkan disiplin positif siswa. Penyebabnya karena siswa beranggapan bahwa saat siswa rajin dan tertib mengikuti pelajaran IPA akan berdampak positif/bermanfaat bagi siswa.

Tabel 7. Disiplin Mengikuti Pelajaran Sains

\begin{tabular}{|c|c|c|c|c|c|c|c|}
\hline \multicolumn{3}{|c|}{ Klasifikasi } & \multirow{2}{*}{$\%$} & \multirow{2}{*}{$\begin{array}{l}\text { Standar } \\
\text { deviasi }\end{array}$} & \multirow{2}{*}{ Mean } & \multirow{2}{*}{ Modus } & \multirow{2}{*}{ Median } \\
\hline Rentang & Sikap & Jumlah & & & & & \\
\hline $6.0-10.8$ & Sangat Tidak Baik & 44 & 5,1 & & & & \\
\hline $10.9-15.6$ & Tidak Baik & 70 & 8,1 & & & & \\
\hline $15.7-20.4$ & Cukup & 186 & 21,5 & 1.1 & 3.76 & 4.0 & 4.0 \\
\hline $20.5-25.2$ & Baik & 316 & 36,6 & & & & \\
\hline $25.3-30.0$ & Sangat Baik & 248 & 28,7 & & & & \\
\hline & Total & 864 & 100,0 & & & & \\
\hline
\end{tabular}

Hasil wawancara tersebut menyimpulkan bahwa siswa sangat tertarik untuk mengiktui pelajaran sains di kelas. Hasil ini memberi kesimpulan siswa yang aktif dalam pembelajaran akan memberikan dampak positif. Karena sudah seyogyanya siswa harus melibatkan dirinya dalam disiplin mengikuti pelajaran sains(IPA). Untuk mengembangkan efektivitas pembelajaran aktif, siswa harus melibatkan siswa secara holistik dari pengalaman siswa di kelas.

b. Disiplin dalam Mengerjakan Tugas Sains

Disiplin dalam mengerjakan tugas sains dapat dimaknai bahawa setiap siswa tidak memiliki ketergantungan yang negatif dalam mengerjakan tugas sains yang diberikan oleh gurunya. Hal ini menyatakan bahwa siswa selalu siap dan mandiri saat mendapatkan tugas terkait sains, selain itu menunjukkan kesungguhan siswa dalam belajar disekolah. Jadi dapat disimpulkan Disiplin dalam mengerjakan tugas Sains mempunyai pengaruh signifikan terhadap pertumbuhan disiplin yang positif. Selanjutnya, pada tabel menunjukkan bahwa hasil indikator disiplin mengerjakan tugas sains berada pada kategori baik. Didukung hasil Tabel 8 menunjukkan angka 40,5\% atau 350 dari 864 siswa berada pada kategori baik dan 22,5\% (194 siswa) berada pada kategori sangat baik, hal ini menunjukkan hasil dominan. Disiplin siswa menunjukkan tingginya kategori baik, sehingga menyimpulkan disiplin positif siswa. Faktor tersebut dipengaruhi bahwa siswa lebih tertarik secara mandiri untuk menyelesaikan tugas yang berkaitan dengan sains. Karena dengan begitu sains akan berdampak positif bagi siswa.

Tabel 8. Disiplin dalam Mengerjakan Tugas Sains

\begin{tabular}{|c|c|c|c|c|c|c|c|}
\hline \multicolumn{3}{|c|}{ Klasifikasi } & \multirow{2}{*}{$\%$} & \multirow{2}{*}{$\begin{array}{l}\text { Standar } \\
\text { Deviasi }\end{array}$} & \multirow{2}{*}{ Mean } & \multirow{2}{*}{ Modus } & \multirow{2}{*}{ Median } \\
\hline Rentang & Sikap & Jumlah & & & & & \\
\hline $6.0-10.8$ & Sangat Tidak Baik & 37 & 4.3 & & & & \\
\hline $10.9-15.6$ & Tidak Baik & 57 & 6.6 & & 37 & 40 & 40 \\
\hline $15.7-20.4$ & Cukup & 226 & 26.2 & 1.02 & 3.1 & 4.0 & 4.0 \\
\hline $20.5-25.2$ & Baik & 350 & 40.4 & & & & \\
\hline
\end{tabular}


\begin{tabular}{llll}
$25.3-30.0$ & Sangat Baik & 194 & 22.5 \\
\hline & Total & 864 & 100
\end{tabular}

Hasil wawancara menyimpulkan bahwa siswa sangat tertarik untuk mengerjakan sains secara mandiri yang bertujuan mencapai hasil positif pada pembelajaran sains. asumsinya karena siswa menganggap sains lebih bermanfaat jika dipelajari secara langsung. Menurut siswa dari wawancara menyatakan bahwa jika seseorang antusias dan tertarik mengikuti sains di kelas akan berdampak positif. Kecenderungan minat belajar adalah minat siswa dalam proses belajar dan berusaha mengetahui dan memahami materi (Budiyono \& Antika, 2018).

c. Disiplin Belajar Sains di Rumah

Belajar Sains di Rumah merupakan perilaku setiap siswa yang selalu belajar bukan karena hanya saat di sekolah, akan tetapi di luar jam sekolah siswa memiliki perilaku dan kebiasaan yang senantiasa memgulang kembali pembelajaran. Hal ini menyatakan bahwa siswa selalu siap dan sedia saat mendapatkan tugas yang berkaitan dengan sains, selain itu menunjukkan kesungguhan siswa dalam belajar disekolah. Jadi dapat disimpulkan Disiplin Belajar Sains di Rumah mempunyai pengaruh signifikan terhadap pertumbuhan disiplin yang positif. Hal ini didukung juga dari hasil Tabel 9 menunjukkan angka 37,5\%\% atau 324 dari 864 siswa berada pada kategori cukup. Jika dilihat kembali hasil indikator ini mayoritas siswa mengarah disiplin positif.

Tabel 9. Disiplin Belajar Sains di Rumah

\begin{tabular}{|c|c|c|c|c|c|c|c|}
\hline \multicolumn{3}{|l|}{ Klasifikasi } & \multirow{2}{*}{$\%$} & \multirow{2}{*}{$\begin{array}{l}\text { Standar } \\
\text { deviasi }\end{array}$} & \multirow{2}{*}{ Mean } & \multirow{2}{*}{ Modus } & \multirow{2}{*}{ Median } \\
\hline Rentang & Sikap & Jumlah & & & & & \\
\hline $6.0-1.8$ & Sangat Tidak Baik & 33 & 3.8 & \multirow{5}{*}{0.95} & \multirow{5}{*}{3.39} & \multirow{5}{*}{3.0} & \multirow{5}{*}{3.0} \\
\hline $10.9-15.6$ & Tidak Baik & 96 & 11.1 & & & & \\
\hline $15.7-20.4$ & Cukup & 324 & 37.5 & & & & \\
\hline $20.5-25.2$ & Baik & 317 & 36.7 & & & & \\
\hline $25.3-30.0$ & Sangat Baik & 94 & 10.9 & & & & \\
\hline & Total & 864 & 100 & & & & \\
\hline
\end{tabular}

Wawancara menunjukkan bahwa siswa kurang tertarik untuk mengulang pelajaran sains ketika di rumah namun disisi lain siswa memiliki kesadaran akan urgensi disiplin belajar. Penyebabnya karena siswa cenderung kurang aktif/minat belajar sains saat di luar sekolah. Meskipun demikian, secara perlahan penerapan disiplin indikator ini harus terus dilaksanakan. Kedisiplinan merupakan faktor penting harus ditanamkan dan dilaksanakan dalam kehidupan sehari-hari untuk mencapai keberhasilan dalam segala hal, salah satunya keberhasilan belajar (Wirantasa, 2017).

d. Disiplin Mentaati Tata Tertib

Disiplin mentaati Tata Tertib Sekolah merupakan kebiasaan siswa dalam mematuhi peraturan sekolah. Sehingga disiplin mentaati tata tertib sekolah mempunyai pengaruh signifikan terhadap pertumbuhan disiplin yang positif. Tabel 10 menunjukkan 41,1\% (324 siswa) berkategori sangat baik. Hal ini menunjukkan hasil yang positif, sehingga menyimpulkan siswa memiliki kebiasaan untuk mentaati peraturan di sekolah. Selaras dengan hasil temuan, misalnya siswa selalu masuk tepat waktu saat pembelajaran sains dimulai. 
Tabel 10. Disiplin Mentaati Tata Tertib Sekolah

\begin{tabular}{|c|c|c|c|c|c|c|c|}
\hline \multicolumn{3}{|c|}{ Klasifikasi } & \multirow{2}{*}{$\%$} & \multirow{2}{*}{$\begin{array}{l}\text { Standar } \\
\text { deviasi }\end{array}$} & \multirow{2}{*}{ Mean } & \multirow{2}{*}{ Modus } & \multirow{2}{*}{ Median } \\
\hline Rentang & Sikap & Jumlah & & & & & \\
\hline $8.0-14.4$ & Sangat Tidak Baik & 62 & 7.2 & & & & \\
\hline $14.5-20.8$ & Tidak Baik & 36 & 4.2 & & & & \\
\hline $20.9-27.2$ & Cukup & 136 & 15.8 & 1.18 & 3.95 & 5.0 & 4.0 \\
\hline $27.3-33.6$ & Baik & 274 & 31.7 & & & & \\
\hline $33.7-40.0$ & Sangat Baik & 356 & 41.1 & & & & \\
\hline & Total & 864 & 100 & & & & \\
\hline
\end{tabular}

Asumsi siswa menganggap bahwa siswa yang disiplin adalah bagian tanggung jawab setiap siswa. Hasil tersebut membuktikan bahwa disiplin mematuhi tata tertib sekolah akan berdampak positif terhadap perilaku dan kegiatan pembelajaran mereka. Students with positive discipline will help students to solve each problem and know how to prevent the problem (Sadik, 2018).

\section{Hubungan Sikap dan Disiplin Siswa terhadap Sains}

Kurikulum 2013 memberikan pendekatan baru sebagai tuntutan abad 21, kurikulum 2013 menggunakan pendekatan ilmiah dan berfokus pada siswa produktif, kreatif, inovatif dan afektif yang terintegrasi melalui keterampilan, sikap dan pengetahuan (Atmarizon \& Zaim, 2016) dan pembenahan Kurikulum 2013 bagi pendidikan di Indonesia merupakan upaya peningkatan mutu pendidikan (Khoiriyah dkk., 2017). Abad 21 ini disebut Era globlisasi, di era ini perkembangan sains, teknologi, \& informasi berjalan sangat cepat dan ada persaingan antar bangsa (Suardana dkk., 2018). Hal tersebut mendasari bahwa penelitian sains berkembang sangat pesat. sehingga pada penelitian ini mencoba menganalisis lebih rinci kaitan sains dengan perilaku/karakter.

Meninjau sains berdasarkan isu sosial karakter siswa merupakan salah satu hal terintegrasi dan perlu dioptimalkan. Salah satu caranya adalah dengan melihat hubungan karakter: sikap dan disiplin siswa terhadap sains(IPA). Diharapkan dengan hasil korelasi sikap dan disiplin terhadap IPA dapat memberikan gambaran kaitan perilaku/karakter (psikologi) siswa dengan sains(IPA). Karakteristik IPA adalah memuat konsep-konsep yang bersifat fundamental/dasar yang berguna dalam kehidupan sehari-hari (Marlina dkk., 2017). Karena pengajaran IPA di sekolah semata-mata hanya berorientasi tuntutan kurikulum yang tertuang dalam buku teks (Maimunah, 2016). Salah satu solusi adalah menganalisis hubungan sikap dan disiplin siswa terhadap sains(IPA). Karena, kedua karakter ini sangat berpengaruh pada setiap siswa yang kaitannya dengan pembelajaran IPA (Sains). Alasannya: [1] sikap siswa berperan sebagai penunjang tercapainya tujuan pembelajaran, sikap positif terhadap pelajaran akan cenderung lebih tekun dalam belajar dan mencapai hasil memuaskan (Rijal \& Bachtiar, 2015), [2] Disiplin berperan penting dalam menentukan kesuksesan belajar siswa dan banyak manfaat apabila siswa menerapkan kedisiplinan (Supardi, 2015).

Hasil uji menunjukkan korelasi sikap dan disiplin pada kelas 7 menunjukkan nilai sig sebesar 0,000 . Ketentuan uji korelasi, jika nilai sig $<0,05$, maka Pada kelas 7(VII) terdapat korelasi positif antara sikap dan disiplin terhadap IPA(sains). Sedangkan nilai derajat korelas (Pearson Correlation): 0,939, ini menunjukkan bahwa hubungan sikap dan disiplin siswa terhadap sains pada kelas 7 memiliki hubungan yang sangat kuat. Sedangkan untuk 
korelasi sikap dan disiplin siswa terhadap IPA kelas 8 menunjukkan nilai sig 0,000 . Sehingga pada kelas 8 memunjukkan adanya korelasi antara sikap dan disiplin terhadap IPA(sains). Sedangkan untuk derajat korelasi yang ditunjukkan Pearson Correlation: 0,828, nilai ini menunjukkan bahwa hubungan antara sikap dan disiplin siswa terhadap sains kelas 8 mempunyai hubungan yang sangat kuat. Sedangkan kelas 9, tabel 12 menunjukkan nilai sig 0,000, sehingga dapat disimpulkan kelas 9 variabel sikap dan disiplin siswa terhadap IPA memiliki hubungan. Sedangkan pada derajat korelasi "Pearson Correlation" menunjukkan nilai 0,696 , nilai tersebut memberikan kesimpulan bahwa siswa kelas 9 berkategori hubungan kuat.

Berdasarkan hasil tersebut, kesimpulannya untuk hubungan sikap dan disiplin siswa pada semua tingkat kelas (Kelas 7, kelas 8, kelas 9) SMP memiliki korelasi positif, ini artinya siswa yang memiliki sikap baik(positif) pada IPA(Sains) akan linier dengan disiplinya yang berkorelasi baik(positif). Sedangkan untuk derajat korelasinya untuk siswa kelas 7 berkorelasi sangat kuat, kelas 8 memiliki korelasi sangat kuat, dan kelas 9 SMP berkorelasi kuat. Sehingga dapat disimpulkan dari hasil korealasi menunjukkan sikap positif pada IPA. Harapannya dari hasil tersebut siswa mampu menguasai ilmu sains/IPA di dalam/luar lingkungan sekolah, karena sifat IPA yang khas. Didukung (Amin dkk., 2018) menyatakan sikap peserta didik terhadap sains/IPA perlu dilakukan karena dapat meningkatkan efektivitas dan keberhasilan peserta didik dalam pembelajaran.

\section{KESIMPULAN}

Berdasarkan hasil analisis statistik deskriptif menunjukkan bahwa sikap siswa terhadap sains menunjukkan kategori baik atau sikap positif. Sedangkan hasil disiplin siswa terhadap sains menunjukkan disiplin yang baik dan positif. Hasil tersebut menyimpulkan siswa memiliki karakter baik.

Hasil korelasi disiplin siswa dengan sikap siswa menunjukkan bahwa: kelas 7 berkorelasi sangat kuat, kelas berkorelasi sangat kuat, sedangkan kelas 9 berkorelasi kuat. Semua kelas menunjukkan korelasi positif, ini artinya setiap siswa yang memilki perilaku disiplin yang baik terhadap IPA, maka akan diikuti peningkatan sikap siswa yang baik/positif terhadap IPA (Sains), jadi semakin tinggi nilai derajat korelasi akan mengikuti tingkat kategori korelasinya.

\section{DAFTAR PUSTAKA}

Abdullah, A. (2016). Instilling values character education through playing role model in learning history. International Conference on Ethics in Governance (ICONEG 2016),

Abed, O. H. (2016). Drama-Based Science Teaching and Its Effect on Students' Understanding of Scientific Concepts and Their Attitudes towards Science Learning. International Education Studies, 9(10), 163-173. https://doi.org/URL: http://dx.doi.org/10.5539/ies.v9n10p163

Acosta, M. (2016). Paradigm shift in open education and e-learning resources as teaching and learning in Philippines. Jurnal IImiah Peuradeun, 4(2), 161-172. https://doi.org/http://dx.doi.org/10.26811/peuradeun.v4i2.94

Aithal, P., \& Aithal, S. (2015). An innovative education model to realize ideal education system. International Journal of scientific research and management (IJSRM), 3(3), 2464-2469. http://ijsrm.in/index.php/ijsrm/article/view/450 
Amin, D. I., Sutrisno, S., \& Sigit, D. (2018). Instrumen Asesmen Pemahaman Konseptual Berorientasi Higher Order Thinking Skills Keterampilan Proses dan Sikap terhadap Sains pada Bahan Kajian Hidrokarbon dan Minyak Bumi. Jurnal Pendidikan: Teori, Penelitian, dan Pengembangan, 3(9), 1142-1146. https://doi.org/http://dx.doi.org/10.17977/jptpp.v3i9.13342

Astalini, A., Kurniawan, D. A., Kurniawan, N., \& Anggraini, L. (2019). Evaluation of Student's Attitude toward Science in Indonesia. Open Journal for Educational Research $3(1)$, 1-12. https://doi.org/https://doi.org/10.32591/coas.ojer.0301.01001a

Atmarizon, D., \& Zaim, M. (2016). The Implementation of Scientific Approach in Teaching English at the Tenth Grade of Senior High School 7 Padang. Komposisi: Jurnal Pendidikan Bahasa, Sastra, dan Seni, 17(1), 1-18. https://doi.org/ https://doi.org/10.24036/komposisi.v17i1.8113

Bennett, J. (2003). Teaching and learning science: A guide to recent research and its applications. A\&C Black.

Budiyono, A., \& Antika, L. T. (2018). REVIEW m: WHAT IS THE DESCRIPTION OF STUDENTS'INTEREST IN PHYSICS? Jurnal Pena Sains, 5(2), 114-120. https://doi.org/https://doi.org/10.21107/jps.v5i2.3776

Chowdhury, M. (2018). Emphasizing morals, values, ethics, and character education in science education and science teaching. MOJES: Malaysian Online Journal of Educational Sciences, 4(2), 1-16. https://research.monash.edu/en/publications/emphasizing-morals-values-ethicsand-character-education-in-scien

Cohen, L., Manion, L., \& Morrison, K. (2013). Research methods in education. routledge.

Creswell, J. W. (2002). Educational research: Planning, conducting, and evaluating quantitative. Prentice Hall Upper Saddle River, NJ.

Damrongpanit, S. (2019). Factors Affecting Self-Discipline as Good Citizens for the Undergraduates of Chiang Mai University in Thailand: A Multilevel Path Analysis. Universal Journal of Educational Research, 7(2), 347-355.

Fahmy, R., Bachtiar, N., Rahim, R., \& Malik, M. (2015). Measuring student perceptions to personal characters building in education: an Indonesian case in implementing new curriculum in high school. Procedia-Social and Behavioral Sciences 211 , 851-858. https://doi.org/https://doi.org/10.1016/j.sbspro.2015.11.112

Febriana, M., Al Asy'ari, H., Subali, B., \& Rusilowati, A. (2018). Penerapan model pembelajaran Inquiry Pictorial Riddle untuk meningkatkan keaktifan siswa. Jurnal Pendidikan Fisika dan Keilmuan (JPFK), 4(1), 10-16. https://doi.org/http://doi.org/10.25273/jpfk.v4i1.1879

Holstermann, N., Grube, D., \& Bögeholz, S. (2010). Hands-on activities and their influence on students' interest. Research in science education, 40(5), 743-757. https://link.springer.com/article/10.1007/s11165-009-9142-0

Joshi, A., Kale, S., Chandel, S., \& Pal, D. K. (2015). Likert scale: Explored and explained. Current Journal of Applied Science and Technology, 396-403. https://doi.org/https;//10.9734/BJAST/2015/14975

Kang, H. T., \& Noh, S. G. (2017). The Effect on Elementary Science Education Based on Student's Pre-Inquiry. Universal Journal of Educational Research, 5(9), 1510-1518. https://eric.ed.gov/?id=EJ1151854

Khoiriyah, A. J., Zubaidah, S., \& Syamsuri, I. (2017). Penerapan Inkuiri Terpimpin Dalam Pembelajaran IPA Untuk Meningkatkan Sikap Sosial dan Pengetahuan Siswa Kelas VII. Jurnal Pendidikan: Teori, Penelitian, dan Pengembangan, 2(3), 409-415. https://doi.org/http://dx.doi.org/10.17977/jptpp.v2i3.8658 
Khuzwayo, M. E. (2018). Assessment of group work in initial teacher education and training. South African Journal of Education, 38(2), 1-11. https://doi.org/https://doi.org/10.15700/saje.v38n2a1386

Kusumaningsih, D. (2013). Indonesian text role as draft science in curriculum 2013: assessment introduction text structure strategies in an indonesian book. Asian Journal of Sciences and Humanities, 2(4), 1-4. http://www.ajssh.leenaluna.co.jp/ajsshvol2n4.php

Lickona, T. (2004). Character matters: How to help our children develop good judgment, integrity, and other essential virtues. Simon and Schuster.

Lucardie, D. (2014). The impact of fun and enjoyment on adult's learning. ProcediaSocial and Behavioral Sciences, 142, 439-446. https://doi.org/https://doi.org/10.1016/j.sbspro.2014.07.696

Maimunah, M. (2016). Penggunaan Model Pembelajaran Science Environment Technology and Society (Sets) untuk Meningkatkan Kemampuan Berpikir Kritis dan Sikap IImiah. Formatif: Jurnal IImiah Pendidikan MIPA, 6(2). https://doi.org/http://dx.doi.org/10.30998/formatif.v6i2.947

Manan, M. (2015). The Implementation of the right to education in Indonesia. Indon. $L$. Rev., 5, 51. https://doi.org/Http://Dx.Doi.Org/10.15742/Irev.V5n1.137

Marlina, M., Utaya, S., \& Yuliati, L. (2017). Pengaruh Authentic Problem Based Learning (aPBL) Terhadap Penguasaan Konsep Ipa Siswa Kelas Iv Sekolah Dasar. Jurnal Pendidikan: Teori, Penelitian, dan Pengembangan, 2(11), 15091514. https://doi.org/http://dx.doi.org/10.17977/jptpp.v2i11.10223

Mohammad-Davoudi, A. H., \& Parpouchi, A. (2016). Relation between team motivation, enjoyment, and cooperation and learning results in learning area based on team-based learning among students of Tehran University of medical science. Procedia-Social and Behavioral Sciences, 230, 184-189. https://doi.org/https://doi.org/10.1016/j.sbspro.2016.09.023

Nursa'adah, F. P. (2015). Pengaruh Metode Pembelajaran dan Sikap Siswa Pada Pelajaran IPA Terhadap Hasil Belajar IPA. Formatif: Jurnal IImiah Pendidikan MIPA, 4(2). https://doi.org/http://dx.doi.org/10.30998/formatif.v4i2.145

Prihantoro, C. R. (2015). The perspective of curriculum in Indonesia on environmental education. International Journal of Research Studies in Education, 4(1), 77-83. https://doi.org/https://doi.org/10.5861/ijrse.2014.915

Puspita, A. M. I. (2019). Peran Budaya Literasi Pada Peningkatan Karakter Siswa Sekolah Dasar [Role Of Literation Culture On The Improvement Of Elementary School Student Characters]. PEDAGOGIA: Jurnal Pendidikan, 8(1), 105-113. https://doi.org/https://doi.org/10.21070/pedagogia.v8i1.2032

Rijal, S., \& Bachtiar, S. (2015). Hubungan antara Sikap, Kemandirian Belajar, dan Gaya Belajar dengan Hasil Belajar Kognitif Siswa. Jurnal Bioedukatika, 3(2), 15-20. https://doi.org/http://dx.doi.org/10.26555/bioedukatika.v3i2.4149

Rumahlatu, D., Huliselan, E. K., \& Takaria, J. (2016). An Analysis of the Readiness and Implementation of 2013 Curriculum in the West Part of Seram District, Maluku Province, Indonesia. International Journal of Environmental and Science Education, 11(12), 5662-5675. https://eric.ed.gov/?id=EJ1115675

Sadik, F. (2018). Children and Discipline: Investigating Secondary School Students' Perception of Discipline through Metaphors. European journal of educational research, 7(1), 31-45. https://eric.ed.gov/?id=EJ1166111

Sparapani, E. F., \& Perez, D. (2015). Perspective on the standardized curriculum and its effect on teaching and learning. Journal of Education \& Social Policy, 2(5), 78-87. http://jespnet.com/journal/index/2237

Suardana, I. N., Redhana, I. W., Sudiatmika, A., \& Selamat, I. N. (2018). Students' Critical Thinking Skills in Chemistry Learning Using Local Culture-Based 7E

Jurnal Pendidikan Fisika dan Keilmuan (JPFK), Vol. 5, No. 2, September 2019, 59-71. 
Learning Cycle Model. International Journal of Instruction, 11(2), 399-412. https://doi.org/https://doi.org/10.12973/iji.2018.11227a

Sumiati, E., Septian, D., \& Faizah, F. (2018). Pengembangan modul fisika berbasis Scientific Approach untuk meningkatkan Keterampilan Proses Sains siswa. Jurnal Pendidikan Fisika dan Keilmuan, 4(2), 75-88. https://doi.org/ http://doi.org/10.25273/jpfk.v4i2.2535

Supardi, S. (2015). Peran kedisiplinan belajar dan kecerdasan matematis logis dalam pembelajaran matematika. Formatif: Jurnal IImiah Pendidikan MIPA, 4(2). https://doi.org/ http://dx.doi.org/10.30998/formatif.v4i2.142

Trisnawati, D. D. (2013). Membangun disiplin dan tanggung jawab siswa SMA Khadijah Surabaya melalui implementasi tata tertib sekolah. Kajian Moral dan Kewarganegaraan, 2(1),

397-411. https://jurnalmahasiswa.unesa.ac.id/index.php/jurnal-pendidikankewarganegaraa/article/view/2658

Ugurlu, C. T., Beycioglu, K., Kondakcı, Y., Sincar, M., Yıldırım, M. C., Ozer, N., \& Oncel, A. (2015). The views of teachers towards perception of discipline in schools. Procedia-Social and Behavioral Sciences, 197, 120-125.

Ulstad, S. O., Halvari, H., Sørebø, Ø., \& Deci, E. L. (2016). Motivation, learning strategies, and performance in physical education at secondary school. Advances in Physical Education, 6(1), 27-41. https://doi.org/http://dx.doi.org/10.4236/ape.2016.61004

Warsito, W., \& Asrowi, A. (2017). Effectiveness of Social Science Learning Based on Noble Values of Ki Hajar Dewantaras Teaching to Strengthen the Students Character. International Journal of Active Learning, 2(1), 1-14. https://doi.org/ https://doi.org/10.15294/ijal.v2i1.9388

Wati, A., Susilo, H., \& Sutopo, S. (2018). Pengaruh Pembelajaran Inkuiri Terbimbing Berbantuan Jurnal Belajar terhadap Penguasaan Konsep IPA Siswa. Jurnal Pendidikan: Teori, Penelitian, dan Pengembangan, 3(1), 129-133. https://doi.org/http://dx.doi.org/10.17977/jptpp.v3i1.10411

Widodo, R. A., \& Pranata, M. (2018). Penerapan Grafik Klip dalam Pendidikan Karakter untuk Pembelajaran Sikap di Sekolah Menengah. Jurnal Pendidikan: Teori, Penelitian, dan Pengembangan, 3(4), 491-496. https://doi.org/http://dx.doi.org/10.17977/jptpp.v3i4.10794

Winkler, J. L., Walsh, M. E., de Blois, M., Maré, J., \& Carvajal, S. C. (2017). Kind discipline: Developing a conceptual model of a promising school discipline approach. Evaluation and Program Planning, 62, 15-24. https://doi.org/https://doi.org/10.1016/j.evalprogplan.2017.02.002

Wirantasa, U. (2017). Pengaruh kedisiplinan siswa terhadap prestasi belajar Matematika. Formatif: Jurnal IImiah Pendidikan MIPA, 7(1). https://doi.org/http://dx.doi.org/10.30998/formatif.v7i1.1272 